\title{
WHEN A RELATIONSHIP HAS REACHED ITS EXPIRATION DATE, DOES THE SAME APPLY TO THE EMBRYOS UNDER SOUTH AFRICAN LAW?*
}

\author{
C van Niekerk \\ LLB LLM \\ Lecturer, Department of Private Law \\ University of the Western Cape
}

\begin{abstract}
SUMMARY
Individuals are more frequently having recourse to assisted reproductive technologies (ART) to realize their desire for offspring. Where they do so, they may choose to fertilize their gametes and implant the resultant embryos immediately, or they may choose to freeze their embryos for later use. The latter option brings with it greater potential for legal disputes as relationships terminate, parties change their minds, and disagreements arise regarding the fate of frozen embryos. This article, therefore, examines the South African legal framework for addressing disputes involving frozen embryos. The aim is to assess whether the current legal framework is adequate, and whether lessons can be learnt from other jurisdictions faced with similar legal disputes.
\end{abstract}

\section{INTRODUCTION}

Any relationship in which individuals decide to bring a child into the world entails some level of introspection. This decision is further accompanied by an awareness that, once the child is born, the other party becomes a permanent fixture in one's life. ${ }^{1}$ This is the case regardless of whether procreation occurs sexually or artificially. ${ }^{2}$ However, as is the case with any relationship, there is no guarantee that it will last. This is evident from the

This article originates from a paper presented at the Private Law and Social Justice Conference held at Nelson Mandela Metropolitan University, Port Elizabeth, 22-23 August 2016.

1 This excludes those instances where a donor is involved. In this instance according to $s$ 40 (3) of the Children's Act 38 of 2005 such individuals acquire no responsibilities, rights, duties or obligations in respect of the child.

2 Although it is arguable that the decision to procreate artificially is accompanied by additional considerations, given the process involved in becoming pregnant. Some of these considerations include: whether use will be made of donor gametes or surrogacy or whether to use fertility treatment in the hope of falling pregnant oneself. 
number of divorces finalized each year. ${ }^{3}$ And in each of those instances where children are involved, the process of deciding their fate makes matters a lot more complex and often comes with varying emotions and arguments about what is in their best interests. In some instances individuals are able to reach harmonious outcomes on their own, while in others it is left for a court to decide what is best for the children concerned. The advent of assisted-reproductive technologies (ART) has not improved matters. In fact, an already complex matter becomes more complicated by the existence of cryopreservation of gametes and embryos. ${ }^{4}$ Now, instead of having to decide the fate of an existing child or children, couples who have undergone ART and have opted to freeze their embryos for future use, are more frequently being caught up in legal disputes about the fate of their frozen embryos upon the termination of their relationship. ${ }^{5}$ This was the case for actress Sofia Vergara of Modern Family fame and her erstwhile fiancé, Nick Loeb. What had started out as the decision of a couple in love, ended in a legal battle for custody of their joint embryos.

While such a case has not yet presented itself before any South African court, $^{6}$ it is inevitable, given the increased use of ART for procreation purposes. ${ }^{7}$ This article, therefore, examines the South African legal framework for addressing disputes involving frozen embryos, in particular the impact of section 12(2)(a) of the Constitution of the Republic of South Africa, 1996 (Constitution) on this issue. The aim is to critically assess whether the current legal response is adequate, or whether lessons can be learnt from other jurisdictions faced with similar legal disputes. In order to achieve this objective, this article considers the Vergara-Loeb saga, it provides a brief introduction to ART, and thereafter it will examine the South African legal framework, as well as foreign responses to the problem. The article then concludes by making recommendations for the way forward.

3 Statistics SA in their 2014 report on Marriages and Divorces found that 150852 civil marriages, 3062 customary marriages and 1144 civil unions were solemnized in 2014; in the same year, 24689 people got divorced. This is 3,4\% higher than in 2013. See Statistics South Africa "Marriages and Divorces 2014" 9 February 2016 http://www.statssa. gov.za/publications/P0307/P03072014.pdf (accessed 2016-08-16) 5.

4 Cryopreservation is defined by the World Health Organisation (WHO) as "[t]he freezing or vitrification and storage of gametes, zygotes, embryos or gonadal tissue". See WHO "The International Committee for Monitoring Assisted Reproductive Technology (ICMART) and the World Health Organization (WHO) Revised Glossary on ART Terminology, 2009" http://www.who.int/reproductivehealth/publications/infertility/art_terminology.pdf (accessed 2016-03-14).

5 MacElree Harvey Attorneys "The Legal Uncertainty Surrounding the Disposition of Frozen Embryos in American Divorce Proceedings" (undated) http://www.macelree.com/the-legaluncertainty-surrounding-the-disposition-of-frozen-embryos-in-american-divorceproceedings/ (accessed 2016-05-24).

6 Breen-Portnoy "Frozen Embryo Disposition in Cases of Separation and Divorce: How Nahmani v Nahmani and Davis $v$ Davis Form the Foundation for a Workable Expansion of Current International Family Planning" 2013 28(1) Maryland Journal of International Law 275 275-276 notes that the "Israeli and American jurisprudence on this issue, though limited, far outstrips the current international dialogue, particularly in regard to the issue of frozen-embryo disposition in cases of separation and divorce".

7 Breen-Portnoy 2013 28(1) Maryland Journal of International Law 276 notes that "the cryopreservation of embryos and the issue of their 'custody' are such recent innovations that international law has not yet caught up with medical developments". 


\section{A BACKGROUND TO THE VERGARA-LOEB SAGA}

The saga which erupted in the United States of America (USA) between Sofia Vergara and Nick Loeb serves as what is fast becoming a classic example of how cryopreservation of embryos can become problematic. ${ }^{8}$ In this instance Ms Vergara and Mr Loeb had been in a relationship, and had opted to fertilize their gametes and cryopreserve the resultant embryos. Sometime later, their relationship broke down and a dispute arose regarding the future of the embryos. Mr Loeb proceeded to sue Ms Vergara for custody of the embryos. He sought to rescind the agreement that they had entered into, which stipulated that the embryos could only be used with the consent of both parties. Mr Loeb argued that the agreement was invalid as it failed to stipulate what should happen in the event of their relationship dissolving. ${ }^{9}$ Surprisingly, this feature is absent in many agreements concluded with fertility clinics. ${ }^{10}$

Mr Loeb further claimed that, as he was committed to the well-being of his two embryo daughters, he should be granted full custody as well as permission to bring them into the world at a time of his choosing. He added that Ms Vergara had breached their contract by "reneging on their verbal and written agreements to allow the birth of the embryonic children conceived". ${ }^{11}$

In this dispute essentially two issues arise. The first relates to the "Form Directive" used by the reproductive centre. This document did not make provision for a donation option in the event that the parties decided not to utilize the embryos, and nor did it provide for those instances where the parties separate. ${ }^{12}$ Loeb alleged that this violated California law which requires that couples be given the following options for the disposition of their embryos in the event of their separation: the embryos should either be made available to the female or male partner, be donated for research

8 See, eg, Davis v Davis 842 S.W.2d 588 (Tenn. 1992); Kass $v$ Kass 696 N.E.2d 174 (N.Y. 1998); A.Z. v B.Z. 725 N.E.2d 1051 (Mass. 2000); J.B. v M.B. 783 A.2d 707 (N.J. 2001); Reber v Reiss 42 A.3d 1131 (Pa. Super. Ct. 2012); Szafranski v Duston 34 N.E.3d 1132 (III. App. Ct. 2015).

9 Mr Loeb, who initially filed a suit against Ms Vergara in 2014, was in 2015 allowed to amend his lawsuit, one in which he would seek full custody of his embryo daughters. See McCartney "Loeb vs Vergara Embryo Suit Gets Court Ruling" 22 May 2015 USA Today http://www.usatoday.com/story/life/tv/2015/05/22/loeb-vs-vergara-embryo-suit-gets-courtruling/27800753/ (accessed 2016-10-10). The hearing has been set down for January 2017. See Cook "A-list Clash over Embryos" 24 September 2016 BioEdge http://www.bioedge.org/bioethics/a-list-clash-over-embryos/12012 (accessed 2016-10-07).

10 The reason for this may be because the agreement entered into between the clinic and the parties using their services is essentially one of consent. As such the primary focus of the clinic is on responsibilities and protecting itself from liability. In contrast, the future of frozen embryos is between the parties who opt to fertilize and freeze the products of this union. In this respect, the clinic is merely giving effect to an existing agreement.

11 Hendershott and Cavello "The Real Costs of the Infertility Industry" 16 June 2015 The Catholic World Report http://www.catholicworldreport.com//tem/3955/The_Real_Costs_of_ the_Infertility_Industry.aspx (accessed 2016-10-06).

12 This is currently the position in South Africa. Few clinics make provision for this option. 
purposes, or to another couple or disposed of in any other clearly-indicated manner. ${ }^{13}$ This argument will be dealt with below.

The second issue pertained to the test to be applied in these instances. Up until this point a "balancing test" had been applied, one which weighs the interests of one gamete donor against that of the other. Loeb made the argument that the Court should consider a third interest, namely, that of the state in potential life. ${ }^{14} \mathrm{He}$ alleged that:

"the United States Supreme Court has held that this is a valid interest and that it exists from the moment of conception.'

The California Supreme Court has also recognized this interest. ${ }^{16}$ Evidence in support of this argument can be found in both California State law and federal law. ${ }^{17}$ Loeb's argument is thus that:

"where there is [a] disagreement over what should be done with embryos, this interest should create a presumption in favour of the person who wants to bring them to term."

In essence, Loeb's petition asked nothing from Vergara - except the ability to allow the embryos they conceived together to come into the world. ${ }^{19}$ Whether this is a legally-permissible argument on his part will also be considered below. But first it is necessary to briefly explain the biology that gives rise to disputes of this nature.

\section{A BRIEF INTRODUCTION TO ARTIFICIAL REPRODUCTION}

When parties decide to engage in artificial reproduction with the specific purpose of producing embryos for future use, gametes - that is, the male and female reproductive cells - are donated or extracted and fertilized in vitro. ${ }^{20}$ The fertilized gametes are now known as a zygote, which is the term used to describe the fertilized organism from the moment of fertilization until

13 Cromwell "What Nick Loeb's New Action against Sophia Vergara means" 26 May 2015 The Federalist http://thefederalist.com/2015/05/26/what-nick-loebs-new-action-against-sophiavergara-means/ (accessed 2015-07-10).

14 Ibid.

15 See, eg, Webster v Reproductive Health Services 492 U.S. 490 (1989) 519, where the United States Supreme Court recognized "the State's interest in protecting potential human life" and saw no reason why this interest should only be recognized from the time the foetus becomes viable.

16 See fn 13 above.

17 Cromwell 26 May 2015 The Federalist http://thefederalist.com/2015/05/26/what-nick-loebsnew-action-against-sophia-vergara-means/ notes that "[t]he California legislature has recognized that unborn children have potential interests, and therefore enacted Cal. Civ. Code $\S 43.1$, which states that '[a] child conceived, but not yet born, is deemed an existing person, so far as necessary for the child's interests in the event of the child's subsequent birth"'.

18 Ibid.

19 See fn 13 above.

20 This is an ART procedure that involves spontaneous fertilization of an egg and sperm cell outside the human body. See the Definitions in the Regulations Relating to Artificial Fertilisation of Persons, GN 175 in GG 35099 dated 2012-03-02. 
four days thereafter. ${ }^{21}$ It is at this point that the zygote becomes a blastocyst. This stage occurs between five and nine days after fertilization. It is during this period that implantation into the uterine wall takes place. It is also during this stage that the blastocyst or pre-embryo is frozen for future use. ${ }^{22}$ Once this occurs, embryonic development is interrupted until the pre-embryo is thawed and implanted into the uterus. At approximately 14 days after fertilization - interruptions not included - the blastocyst becomes an embryo and for the next six weeks the embryonic cells continue to develop until they form a foetus. What is evident from this is that at the stage of freezing the pre-embryo is not yet a foetus, which is an important consideration in reaching a definitive solution on this issue. ${ }^{23}$

\section{THE SOUTH AFRICAN LEGAL POSITION}

At present the ownership of embryos is regulated by the Regulations Relating to Artificial Fertilisation of Persons (Regulations), ${ }^{24}$ promulgated in terms of the National Health Act $(\mathrm{NHA}){ }^{25}$ The other legislation that may potentially weigh in on this issue is section 12(2)(a) of the Constitution, which will be considered below.

\section{The Regulations}

The law concerning artificial fertilization is set out in the Regulations, which endeavour to regulate all processes dealing with artificial fertilization.

Regulation 18 specifically deals with the issue of the "[o]wnership of gametes, zygotes and embryos". ${ }^{26}$ This regulation states that once artificial fertilization has occurred, "the ownership of a zygote or embryo ... is vested in the recipient." ${ }^{27}$

This provision is problematic for two reasons. Regulation 18 fails to make mention of those instances where embryos are being cryopreserved for future use. In this instance fertilization has taken place, but it is possible that no one is a "recipient" as defined in the Regulations. In those instances where no such person has been nominated, the Regulations fail to provide an answer.

The second problem relates to the use of the term "ownership". "Ownership" has been defined in numerous Court decisions as:

21 Robertson "In the Beginning: The Legal Status of Early Embryos" 199076 Virginia LR 437 441.

22 Robertson 199076 Virginia LR 443.

23 The status of the embryo under South African law is still uncertain, although it is clear from existing legislation that the foetus and embryo are treated differently. For example, under SA law, terminations of pregnancy are permitted more easily during the first trimester when the procreative tissue is an embryo, than when it is a foetus.

24 See fn 20 above.

2561 of 2003.

26 Author's own emphasis.

27 Reg 18(2). 
"the most complete real right which gives the owner the most complete and absolute entitlements to a thing".

A thing in turn has been defined as:

"as a corporeal or tangible object external to persons and which is, as an independent entity, subject to juridical control by a legal subject, to whom it is useful and of value".

These definitions, when read alongside Regulation 18, suggest that gametes and embryos qualify as property. Such an interpretation raises the following question: Was this the intention of the legislature? If so, then the framing of Regulation 18 makes sense, as ownership generally vests in the person in possession of the property. And does such an interpretation mean that South African law has definitively excluded the possibility that an embryo is neither a person nor something in-between person and property, which requires special consideration? I submit not. Mahomed et al appear to agree when they assert that:

"our current legislation does not provide guidance on whether an embryo may fulfil the requirements to be property. Therefore, the exact characterisation of an embryo in South African law remains unknown".

They further agree that the use of the word "ownership" in the Regulations is problematic and suggest that it should be "substituted with a "proprietary interest', which denotes something different from the legal understanding of ownership".

From the aforementioned it becomes apparent that the Regulations are of limited assistance in resolving the issue of embryo disputes. Whether section 12(2)(a) provides any insight into this situation will be considered next.

\section{Section 12(2)(a) of the Constitution}

Section 12(2)(a) of the Constitution recognizes the right of individuals to make decisions regarding reproduction. This right has been interpreted as affording individuals the freedom to avoid procreation. This position has been confirmed in both case law and statute. For example, in both the Christian Lawyers Association of SA v Minister of Health cases ${ }^{32}$ the Court recognized the application of the right in section 12(2)(a) within the context of a termination of pregnancy. Similarly, the preambles of both the Choice on Termination of Pregnancy $A_{c t} t^{33}$ and the Sterilisation $A_{c t} t^{34}$ affirm their

\footnotetext{
Van der Walt and Pienaar Introduction to the Law of Property 5ed (2006) 39-47.

Ibid.

30 Mahomed, Nothling-Slabbert and Pepper "The Legal Position on the Classification of Human Tissue in South Africa: Can Tissues be Owned?" 2013 6(1) South African Journal of Bioethics and Law 1619.

31 Ibid.

321998 (4) SA 1113 (T); 2005 (1) SA 509 (T). In the first case, the Court considered the constitutionality of the Choice on Termination of Pregnancy Act, while in the second case the Court considered whether a girl under the age of 18 years, in exercising her rights in $\mathrm{s}$ 12(2)(a) could terminate her pregnancy without parental consent.

3392 of 1996.
} 
connection to section 12(2)(a). Sadly, no similar connection has been made between the section 12(2)(a) and the right to reproduce, either sexually or artificially. ${ }^{35}$ The status of this "right" is thus unclear. At present section 12(2)(a) therefore does not aid parties wishing to procreate under these circumstances. ${ }^{36}$ Courts may thus rule in favour of avoiding procreation, which translates into the disposal of embryos where disputes arise. This position is untenable as choosing to procreate is as much a part of selfdetermination as choosing to avoid procreation. This begs the question: how should South Africa proceed? What follows is an examination of legal disputes in other jurisdictions in order to find possible solutions.

\section{FOREIGN CASE LAW}

\section{$51 \quad G$ and $G$ (Australia)}

In $G$ and $G^{37}$ the Western Australian Family Court was called upon to decide the fate of six frozen embryos which had been created by a couple whose relationship had since broken down. At the time of cryopreservation the female was suffering from endometriosis which required treatment that would prove harmful to her existing ova. The dispute arose because Mrs G wanted the embryos discarded, while Mr G, who believed this to be his only remaining opportunity to procreate ${ }^{38}$ wanted them to be transferred into his custody. His intention was not to use them personally, but rather to donate them to an infertile couple. However, prior to freezing the embryos, the couple had signed an agreement in which they indicated that the frozen embryos were to be discarded in the event of their separation.

The Court, in reaching its decision referred to both Australian law ${ }^{39}$ on the subject as well as foreign decisions ${ }^{40}$ involving similar circumstances. The Court found that:

"[t]he embryos should be allowed to succumb as the parties have now separated and can no longer achieve the purpose for which they consented to create and use the embryos".

34 of 1998.

35 Academics such as Currie and De Waal The Bill of Rights Handbook 6ed (2013) 286 provide limited insight into the meaning of "making decisions regarding reproduction" under $\mathrm{s} 12(2)(\mathrm{a})$ and whether it extends to the decision to procreate.

36 Parties could at best rely on $s 14$ of the Constitution to assist them. This provision recognizes that "[e]veryone has the right to privacy". This provision is arguably a variation of Article 8 of the European Convention for the Protection of Human Rights and Fundamental Freedoms (ECHR) (1950) which has aided parties in vindicating their rights to reproduce artificially.

37 [2007] FCWA 80.

$38 \quad G$ and $G$ supra par 21.

39 Reference was in particular made to s 26(1)(a) of the Human Reproductive Technology Act 1991.

40 The Court (par 44) amongst other referred to the English case of Evans $v$ Amicus Health Care Ltd; Hadley v Midland Fertility Ltd [2003] EWHC 2161 (Fam), [2004] 2 WLR 713 (Eng) where the two female applicants sought permission to use the embryos created with their partners after the relationships had terminated. In both instances the British High Court dismissed the applications, finding that "the men had an unconditional statutory right to withdraw or vary their consent".

$41 \quad G$ and $G$ supra par 61. 
This case clearly followed contract principles despite the husband's allegation that he had no further opportunities to procreate. In this instance the Court appears not to have attached much weight to his assertion, as he was not the one suffering from endometriosis. This case raises the question whether such an assertion by the wife would have produced a different result.

\section{Findley $v$ Lee (USA)}

In Findley $v$ Lee $e^{42}$ the dispute involved the disposition of embryos created by the parties after the wife had been diagnosed with breast cancer. In this case the parties had entered into an agreement with the IVF programme in which they clearly indicated that, in the event of divorce, the embryos were to be destroyed. Dr Lee disputed the agreement, alleging that:

"her informed consent was not properly obtained and that a balancing test should be applied in which her constitutional right to procreate should trump".

The Court ultimately found in Mr Findley's favour, ostensibly vindicating "his right not to procreate despite [his] ex-wife's infertility". ${ }^{44}$ In its decision the Court made a number of important observations. It rejected the argument that either party's right to procreate or not to procreate was implicated. ${ }^{45}$ It further ruled that both parties had "waived their rights by entering into the contract and making their elections in the event of divorce or death." ${ }^{46}$

The Court also addressed the issue of whether embryos are property or persons. It found as follows:

"To suggest that this Court should find that these five 'viable' embryos are simplv propertv undermines not onlv the express lanquaqe in the Consent \& Agreement, but ignores the very reason couples undergo the emotionally and financially draining process of IVF: To have a child.

It simply is not necessarv in this case to cateqorize the embrvos as 'life' or 'property.' The reality is that the embryos and their creators, Lee and Findley, deserve somethina more nuanced .... the embrvos in this case represent the nascent staqe of five human lives. Thev are not propertv, nor are thev fully formed human beinas. Thev are, in the construct of the law, sui generis and will be deemed as such in this statement of decision."

While this decision followed a contractual approach it provided great insight into the arguments raised by the parties in similar disputes. Fortunately for the Court, there was a pre-existing agreement which could be relied upon. Matters are more complex when no such agreement exists.

42 No FDI-13-780539 (Cal. Super. Ct. Jan. 11, 2016).

43 Crockin "California Trial Upholds Couple's Agreement with UCSF and Orders Pre-embryos Discarded" 16 December 2015 ASRM News https://www.asrm.org/California Trial _Court_Upholds_Couples_Agreement_with_UCSF_and_Orders_Pre-embryos_Discarded/ (accessed 2016-08-20).

44 Cohen and Adashi "Embryo Disposition Disputes: Controversies and Case Law" 2016 46(5) Hastings Centre Report 1314.

45 Findley $v$ Lee 65.

46 See fn 43 above.

$47 \quad$ Findley $v$ Lee supra 82. 


\section{Davis v Davis (USA)}

In Davis $v$ Davis, ${ }^{48}$ the plaintiff filed for divorce from his wife. While the parties were able to reach an agreement regarding the terms of the dissolution of their marriage, they were unable to do so regarding the seven embryos stored in a fertility centre. This case proceeded "through three levels of the Tennessee judicial system", with each Court arriving at a different conclusion. ${ }^{49}$

The trial court awarded custody to Mrs Davis, finding that the embryos were "human beings". ${ }^{50}$ The appellate court reversed this decision and awarded joint-custody to both parties. It reasoned that Mr Davis had a "constitutionally protected right not to beget a child where no pregnancy has taken place." ${ }^{51}$ Furthermore, the Court found "no compelling State interest to justify ordering implantation against the will of either party". ${ }^{2}$ The Supreme Court of Tennessee began its analysis by attempting to clarify the legal status of the pre-embryos. It concluded that the pre-embryos were not persons or property, but in a special category that deserved "special respect because of their potential for human life". ${ }^{53}$ Therefore, based on their interest in (rather than their ownership of) the pre-embryos, the parties had decisionmaking authority over its disposition. ${ }^{54}$ Next, the Court discussed whether the parties will become parents. The Court examined the right to privacy and concluded that "the right of procreational autonomy is composed of two rights of equal significance - the right to procreate and the right to avoid procreation". ${ }^{55}$ After balancing these two conflicting constitutional interests, the Court concluded that Mr Davis's interest in avoiding genetic parenthood outweighed his ex-wife's right to procreate by donating the embryos to another couple. ${ }^{56}$ The Court, however, noted that it would have reached a different outcome if Mrs Davis had wanted to use the embryos herself and had no other means of achieving parenthood. ${ }^{57}$ The Court commented that any proposed state interest in preserving the life of the embryo "is at best slight," reasoning that:

"when weighed against the interests of the individuals and the burdens inherent in parenthood, the State's interest in the potential life of these preembryos is not sufficient to justify any infringement upon the freedom of these individuals to make their own decisions as to whether to allow a process to continue that may result in such a dramatic change in their lives as becoming parents".

48 Davis v Davis supra 588.

49 Stempel "Procreative Rights in Assisted Reproductive Technology: Why the Angst?" 1999 62(3) Albany LR 11871192.

50 Davis v Davis supra 589.

51 Ibid.

See fn 50 above.

Davis v Davis supra 597.

Ibid.

Davis v Davis supra 601.

Davis v Davis supra 604.

Ibid.

Davis v Davis supra 602. 
This dictum in Davis thus puts paid to the argument advanced by Nick Loeb.

This case is further significant as it was the first to:

"attempt to lay out an analytical framework for disputes between divorcing couples regarding the disposition of frozen embryos".

This ruling suggests that the approach to be followed in such disputes is to firstly determine whether there is an agreement. If there is, it should be considered as valid and binding. Where, however, no such agreement exists, the court must resolve the dispute by weighing the interests of both parties. ${ }^{60}$ In such a case, avoiding procreation should trump procreation, assuming that the other party has a reasonable possibility of achieving parenthood without having recourse to the embryos.

What is also evident from the Davis ruling is that personal use will trump donation to third parties in cases of a dispute. This was also the finding in Nahmani $v$ Nahmani ${ }^{62}$ which will be discussed next.

\section{Nahmani v Nahmani (Israel)}

In Nahmani $v$ Nahmani, the parties decided to procreate by means of in vitro fertilization (IVF) after Mrs Nahmani had lost the ability to reproduce naturally. Their gametes were thus fertilized and stored, with the intention that they be implanted into a surrogate in the USA. Before this could happen, Mr Nahmani left home and fathered a child with another woman. Mrs Nahmani subsequently applied for the release of the embryos. ${ }^{63}$ The trial Court found in her favour, holding that Mr Nahmani's prior agreement to IVF applied to all stages of the procedure ${ }^{64}$ Furthermore, Mr Nahmani could not rely on a change in circumstances when he himself had prompted the change.

Mr Nahmani appealed this decision. The Supreme Court of Israel found in his favour, concluding that it would be improper to force parenthood on him. ${ }^{66}$ The Court further found that concluding otherwise would be a violation of Mr Nahmani's human liberty and procreational autonomy. ${ }^{67}$ The Court added that contractually Mr Nahmani's consent to continue with the IVF was unenforceable. $^{68}$

Mrs Nahmani repetitioned the Court. It reversed its previous decision and awarded the embryos to Mrs Nahmani. ${ }^{69}$ In doing so the Supreme Court

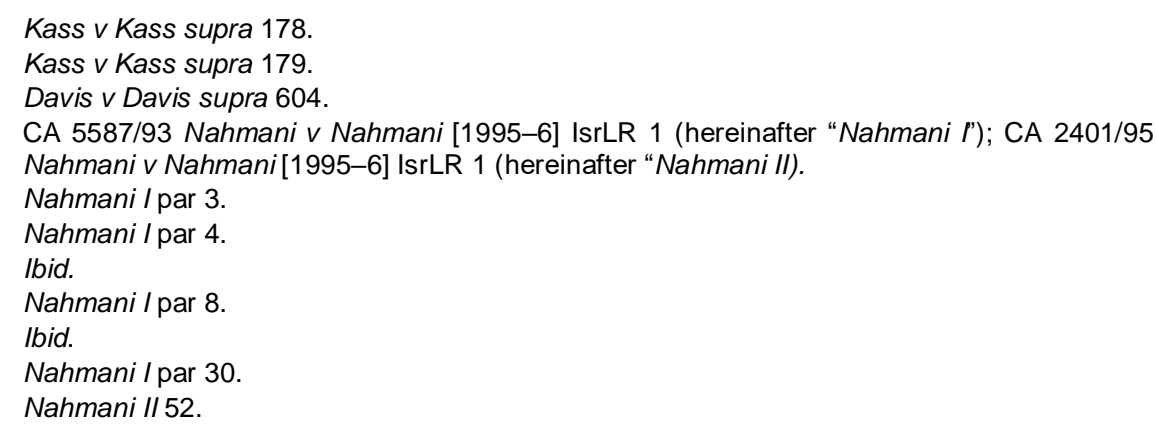


found that her right to reproduce took precedence over Mr Nahmani's right to avoid procreation.

What is interesting to note about this case is that, while the Court's decision vindicated the right to procreate above the right not to procreate, this decision was heavily influenced by the fact that Israel is a pro-natalist state. ${ }^{71}$ Given its religious heritage Israel may in future reach similar decisions regarding the disposition of frozen embryos. ${ }^{72}$

\section{Szafranski v Duston (USA)}

In Szafranski $v$ Duston ${ }^{73}$ the parties created embryos when the defendant was diagnosed with lymphoma which, as a result of her chemotherapy, would ultimately result in ovarian failure and infertility. The couple also entered into an agreement in which the plaintiff agreed that the defendant "should have the opportunity to use such embryos to have a child." ${ }^{74}$ Unfortunately, the agreement was never signed; and when the relationship ended, a dispute arose regarding the fate of the embryos. In this case the Illinois Appellate Court, adopting a combined contractual and balancing-ofinterests approach, found in the defendant's favour. As the agreement was an oral one, the Court abided by it, but simultaneously placed great emphasis on the fact that Ms Dunston would not be able to reproduce otherwise.

In this case the existence of an oral agreement, as opposed to a written one, may explain the Court's approach.

\section{Evans v Amicus Healthcare Ltd (United Kingdom) ${ }^{75}$}

In 2002, the plaintiff, Ms Evans, instituted proceedings against the defendant, Amicus Healthcare, in an attempt to prevent it from destroying frozen embryos that she had created through IVF with her then boyfriend, Howard Johnston. Their relationship had terminated in 2002, and Johnston subsequently withdrew his consent for the embryos to be used. This act thus placed the defendant under an obligation to destroy them. Both the Family Division and the Court of Appeal dismissed the plaintiff's claims, including her claim that the defendant's conduct would violate the embryos' right to life. On appeal, the European Court of Human Rights ${ }^{76}$ (ECtHR)

70 Nahmani ll 66 (par 15).

71 Pro-natalism is defined as "the policy or practice of encouraging the bearing of children, especially Government support of a higher birth rate". See Dictionary.com (undated) http://www.dictionary.com/browse/pronatalist (2016-10-10).

72 Waldman "Cultural Priorities Revealed: The Development of and Regulation of Assisted Reproduction in the United States and Israel" 200616 Health Matrix: Journal of LawMedicine 6568 notes that Israel is "unapologetically pro-natalist". This particular stance is the reason that a couple have been permitted to harvest their dead daughter's eggs in the hope of producing grandchildren. See Conley "Israeli Court Allows Family to Harvest Dead Daughter's Eggs" 11 August 2011 ABC News http://abcnews.go.com/Health/israeli-familypermission-freeze-dead-daughters-eggs/story?id=14272156 (accessed 2016-08-19).

34 N.E.3d 1132 (III. App. Ct. 2015).

74 Szafranskiv Duston supra 504.

75 [2003] EWHC 2161 (Fam); [2004] 2 WLR 713 (Eng).

76 Evans v United Kingdom 43 E.H.R.R. 21415 (2006). 
unanimously dismissed Evans's claim because the United Kingdom did not recognize embryos as human lives and, therefore, their disposal would not constitute a human-rights violations.

In this case the ECtHR clearly rejected the argument that an embryo has a right to life. An embryo therefore does not qualify as a person. Despite this and other rulings, subsequent applicants have not been deterred from raising this argument. ${ }^{77}$

\section{Possible approaches to the disposition of embryos and their legal implications}

From the aforementioned discussion of foreign-case law it becomes apparent that disputes involving frozen embryos has to date been met with three responses: enforcing the existing contract, weighing up the interests of the parties, and determining the status of the embryo. Each will be discussed below.

\section{Enforcement of the contract}

The argument for the enforcement of the embryo-disposition agreement appears to be the simplest option. This option "allow[s] judges to decide cases based on contract principles rather than upon rights-based arguments". ${ }^{78}$ However, this option is only available where an agreement in fact exists. However, even in such instance, this approach may not prove suitable where one party has changed its mind, or where the standard-form contract does not make provision for what should happen in a dispute.

In the former instance, contract modification would then be impossible and one party may be bound to a contract that first, no longer reflects their wishes, and secondly, results in offspring which they no longer wish to beget and rear. Enforcement of the contract is thus only appropriate where the parties' wishes have remained unchanged. Where this is not the case, recourse may be had to one of the following options:

\section{Weighing up the interests of the parties}

Where the agreement is silent on the issue of what should happen in the event of the parties separating, as was the case in the Vergara-Loeb saga, Courts have tended to weigh up the interests of the gamete providers in order to reach a decision. The interests in question are usually the interest of one party in reproducing versus the interest of the other party in avoiding procreation. The argument advanced by Mr Loeb adds another dimension to this option, namely, that the interest of the State in potential life also be considered. This argument suggests that in case of a dispute "the State's

77 Thomas More Society "Thomas More Asserts Scientific Fact: Embryos are Human, not Property" 1 December 2015 https://www.thomasmoresociety.org/thomas-more-societyasserts-scientific-fact-embryos-are-human-not-property/ (accessed 2016-08-20).

78 See fn 5 above. 
interest should create a presumption in favour of the person who wants to bring the embryos to term."

The challenge posed by this argument is that, where the State's interest in potential life becomes a deciding factor in cases of this nature, it has the potential to make inroads into women's rights to terminate their pregnancies, as the State could then arguably have an interest in every potential life created. For this reason alone this argument should be rejected.

\section{Determining the status of the embryo}

The third option in cases of embryo disputes - and by far the option most avoided - is an evaluation into the status of the embryo. To date three responses have emerged. The first views the embryo as a person. ${ }^{80}$ This argument is, however, problematic as the:

"juridical nature of such a construction is objectionable: the legal status of juridical persons consists of both rights and duties. The embryo and fetus cannot be the bearer of duties".

Adopting this view means that a court will invariably rule in favour of the party wishing to procreate.

The second view expressed is that the embryo is not a person, but property. ${ }^{82}$ The ordinary rules regarding property would then determine the right of a party to dispose of the embryos. The notion that embryos are property is often not well received. ${ }^{83}$

The third view expressed is that embryos are neither persons nor property, but that they fall into an:

"intermediate category that entitles them to special respect because of their potential for human life. However, it is not clear whether this implies (a) that embryos are special property, able to be treated as objects of property rights but subject to constraints necessary to ensure respectful treatment, or (b) that embryos cannot be objects of property rights. If embryos are neither persons nor property, interactions with embryos must be regulated, if at all, through sui generis rules:" (footnotes omitted).

Each of the options discussed above brings with it a plethora of questions, some of which are subject to philosophical, legal and moral considerations.

79 See fn 13 above.

80 Schonfeld "'To be or not to be a parent' The Search for a Solution to Custody Disputes over Frozen Embryos” 199815 Touro LR 305312.

81 Slabbert "The Fetus and Embryo: Legal Status and Personhood" 19972 TSAR 234253.

82 See fn 80 above.

83 One of the reasons for this is that such a notion makes "human appear as a commodity". See Mahesh "Law and Regulations Associated with Ownership of Human Biological Material in South Africa" 2015 8(1) South African Journal of Bioethics and Law 11. The Court in Findley $v$ Lee supra 82 was also not willing to acknowledge that embryos are property, as doing so would devalue their worth to their creators.

84 Davis V Davis supra 597; Bennett Moses "The Applicability of Property Law in New Contexts: From Cells to Cyberspace” 200830 Sydney LR 639642. 


\section{The legal implications of choosing one approach above the other}

Regardless of the approach adopted by a court, it comes down to recognizing the right of one party above that of the other. To date Courts have generally tended not to "allow the use of a frozen embryo if one party objects" ${ }^{85}$ In doing so, these courts have sent the message that "the interest of the one who wishes to avoid procreation outweighs the interests of the one who wishes to procreate".

Interestingly, this position is in contrast with jurisprudence dealing with termination of pregnancy. Prior to the advent of ART, in disputes involving the decision to reproduce, versus the decision not to do so, where a female was already pregnant and the male wished to avoid parenthood, the courts have unequivocally held that her right to bodily integrity outweighed the father's right to decide. ${ }^{87}$ In these situations the one party's interest in procreating thus outweighed the other's interest in avoiding procreation. ${ }^{88}$ The tables thus seem to have been turned as far as ART is concerned.

That said, this reversed stance appears to be the norm, except where the party wishing to procreate has no other opportunities to do so. This factor is increasingly impacting on court decisions in disposition cases and may well mean that procreating would trump the avoidance of procreation in certain instances.

In the event of a court either recognizing the embryo as a person or finding that the interest in procreating outweighs the interest in avoiding procreation, some questions are raised regarding the consequences of such decision. Mr Loeb implied that he wanted nothing from Ms Vergara other than her eggs. In reality, parenthood - whether desired or not - brings with it certain responsibilities that cannot be ignored.

The first question that thus arises relates to the status of the party who wants to avoid procreation. Is that party to be given the status of a donor which denies them parental responsibilities and rights? Or is that party to be treated as an unmarried parent who has obligations towards the life created? In most countries a sexual relationship that results in offspring as a minimum requires an unmarried parent to maintain the child. The child also has inheritance rights where the parent is deceased. Would the same apply in this instance? Or does the fact that the embryo was created artificially have some bearing on this situation? Even in the case where the parent wishing

85 Green "New Case Bodes Well for Sofia Vergara in Frozen Embryo Battle" 22 November 2015 MSNBC http://www.msnbc.com/msnbc/new-case-sofia-vergara-frozen-embryos (accessed 2016-05-25)

86 Schonfeld 199815 Touro LR 321.

87 Colb "Verdict - Legal Analysis and Commentary from Justia: Frozen Embryo Disputes" 23 December 2015 Justia https://verdict.justia.com/2015/12/23/frozen-embryo-disputes (accessed 2016-08-17).

88 The reason for this change in stance can possibly be attributed to the fact that termination of pregnancy involves not only a right to decide but also control over one's body, or as Colb https://verdict.justia.com/2015/12/23/frozen-embryo-disputes puts it "[the] right to be free of an assault and battery on one's body". 
to avoid procreation is regarded as a donor, the child still has a right to know its genetic origins, which potentially has some ramifications for the donor. ${ }^{89}$

Clearly, disputes over frozen embryos raise a lot of questions. Even after examining the experiences in foreign jurisdictions, it becomes evident that some of these questions remain unanswered. This raises a further question about how South Africa should navigate what at present constitutes uncharted territory.

\section{THE WAY FORWARD FOR SOUTH AFRICA}

As pointed out, South Africa's current legal framework is inadequate for dealing with disputes involving frozen embryos. However, the jurisprudence from the other jurisdictions discussed in this paper point to three possible ways of remedying this defect. The first, and by far the easiest option, would arguably be to ignore the issue until a case arises which necessitates a response. Unfortunately, this is not ideal as courts often have different approaches on how matters of this nature are to be decided. This is evident from the foreign-case law on this issue. So, until this issue is addressed by either the Supreme Court of Appeal or the Constitutional Court, conflicting approaches are likely to result.

The second option, and the preferable response, would be to amend legislation to provide greater clarity on the options available to the parties. Chapter 19 of the Children's Act ${ }^{\circ 0}$ is dedicated to surrogate-motherhood agreements. It is suggested ${ }^{91}$ that similar legislation be adopted to cater for embryo-disposition agreements. This legislation should, amongst other, include the following:

- A clear distinction should be made between an agreement concluded with a fertility centre which provides for informed consent and an embryodisposition agreement. ${ }^{92}$

- The agreement must be in writing.

- The agreement must be concluded prior to cryopreservation. ${ }^{93}$

- These agreements should be binding even if one party later changes his/her mind. ${ }^{94}$

89 In some countries the fact that donors' identities are no longer anonymous has deterred individuals from donating their gametes. See, eg, Clark "A Balancing Act? The Rights of Donor-conceived Children to Know Their Biological Origins" 2012 40(3) Georgia Journal of International and Comparative Law 619 643; Skopek "Anonymity, The Production of Goods, and Institutional Design" 201482 Fordham LR 17511804.

9038 of 2005.

91 Cohen and Adashi 2016 46(5) Hastings Centre Report 16-17 propose similar guidelines for legislation in the USA.

92 A distinction is necessary as the former agreement is between the clinic and the donors, while the latter is between the parties. The clinic only becomes involved in the disposition agreement where the parties have decided to donate or discard the embryos and need assistance in doing so.

93 This is much the same as a surrogacy agreement which must be concluded before fertilization takes place. This adds to certainty between the parties. Cohen and Adashi 2016 46(5) Hastings Centre Report 17.

94 Ibid. 
- The agreement should clearly indicate the various options available to the parties, ${ }^{95}$ as well as the option selected by them.

- Provision should also be made in the event where one of the parties suffers a loss of fertility and the embryos thus represent their last opportunity for procreation. ${ }^{96}$

- The agreement should also stipulate the legal obligations to be imposed, if any, on the other gamete donor. For example, where the female donor acquires the embryos, the legal obligations of the male donor in respect of any children born should be stipulated. ${ }^{97}$

- It could be argued that the agreement should be confirmed by the High Court as is the case with surrogate-motherhood agreements. However, it is submitted that this is not necessary as a third party such as a surrogate is not involved, and there is thus a smaller possibility of exploitation than in the case of surrogacy which necessitates confirmation by the High Court.

Failing this, the third option would be for fertility centres to formulate a contract, or for the clients themselves to reach an agreement, which makes express provision for the disposition of embryos in the case of separation or divorce. ${ }^{98}$ Like the first option, this one is also not preferred as some of the points raised in option two may be omitted, which could then potentially also result in litigation.

\section{$7 \quad$ CONCLUSION}

The ideal solution to addressing disputes involving frozen embryos is an embryo disposition agreement. Where such agreements exist, preference should then be given to them. In the alternative, the interests of the parties should be balanced. However, in order for either option to be feasible, legislation should ideally exist which sets out the contents of these agreements. In the alternative, some sort of clarity should be reached about the status of the right to reproduce vis-à-vis the right not to reproduce. In Davis $v$ Davis the Court held that "the right of procreational autonomy is composed of two rights of equal significance - the right to procreate and the right to avoid procreation". " Up until now, the right to avoid reproduction has been clearly recognized. A similar finding about the right to reproduce is lacking. This may mean that in the absence of an embryo-disposition agreement, where courts are called upon to balance the interests of the parties, the party wishing to avoid procreation will always triumph, leaving the party wishing to procreate with the short end of the stick.

95 Namely, that the embryos be donated to the female donor, the male donor, third parties, research or that the embryos be discarded.

96 See fn 93 above.

97 Ibid. In theory, the agreement could stipulate that the other gamete donor be treated as an independent donor, without any parental responsibilities and rights.

98 At present Reg 10 makes provision for the destruction of embryos if they have not been claimed after ten years have passed. Such a situation may arise where the parties are unable to reach consensus regarding the disposition of their embryos and which to avoid litigation. However, such a lengthy time period may be untenable for parties whose relationships have terminated soon after cryopreservation has occurred. In the absence of an agreement litigation may then be their only option.

99 Davis v Davis supra 601. 